\title{
Behavior of Murrah buffaloes under influence of strangers in the milk parlor during milk control
}

\section{Análisis comportamental de búfalas Murrah bajo la influencia de personas extrañas en el control lechero}

\author{
Maria Vanderly Andrea, ${ }^{1 *}$ Ph.D, Cintia Righetti Marcondes, ${ }^{2}$ Ph.D, Adriana Bagaldo, ${ }^{1}$ Ph.D, \\ Kaliane Nascimento de Oliveira, ${ }^{1}$ M.Sc, Evani de Oliveira-Strada, ${ }^{1}$ Ph.D, \\ Emanoela Souza-Conde, ${ }^{3}$ M.Sc, Sabrina Luzia G. de Souza, ${ }^{1}$ Ph.D.
}

\begin{abstract}
${ }^{1}$ Universidade Federal do Recôncavo da Bahia, Centro de Ciências Ambientais e Biológicas, Rua Rui Barbosa, 720, CEP 44380.000, Cruz das Almas, Bahia, Brazil..2Embrapa Pecuária Sudeste, Rodovia Washington Luiz, km 234, CEP 13560-970, São Carlos, São Paulo, Brazil. ${ }^{3}$ Instituto Federal de Educação, Ciências e Tecnologia Baiano Campus Teixeira de Freitas, Rodovia BR 101, Km 882, s/n, CEP 45.985-970, Teixeira de Freitas, Bahia, Brazil. *Correspondence: mvander@ufrb.edu.br
\end{abstract}

Received: February 2014; Accepted: December 2014.

\begin{abstract}
Objective. The study was carried out in two farms, located in São Sebastião do Passé, Bahia, Brazil, during the three first months of lactation of 81 female buffaloes, to observe if stranger people at milk parlor could affect the milk production. Materials and methods. Four strangers were at the milking parlor during the milking time to observe the following parameters: Duration of Stay in the Milking Parlor; Milking Period; Rumination; Defecation; Urination Reactivity; Stress Level; Side Preference in the Milking Parlor; Milk Yield, and Post Control Milk Yield. The females were categorized as 1 =primiparous, 2 =pluriparous, and $3=$ when information about calving number was not available. The data were analyzed using SAS Statistical Package. Results. During the presence of four strangers at the milking parlor, it was observed that the mean value for Duration of Stay in the Milking Parlor was 23 minutes (varying from 12 to 38 minutes). Average Milking Period was 8 minutes (varying from 4 to 13 minutes). Average Milk Yield during observation days (MY) varied from $2.30 \mathrm{~kg}$ to $14.70 \mathrm{~kg}$, with an average value of $7.70 \pm 2.60 \mathrm{~kg}$, while Mean Milk Yield after the observation days was $8.600 \pm 2.70 \mathrm{~kg}$. Conclusions. As far as Post Control Milk Yield, since the animals presented increased milk yield in both farms on the days following the observations, it is possible to assert that the presence of strangers in the milk parlor during milk control reduced milk yield only during the day of observation, with no adverse effects on subsequent milk production.
\end{abstract}

Key words: Animal production, animal welfare, Bubalus bubalis (Source: CAB, USDA).

\section{RESUMEN}

Objetivo. El estudio fue realizado en dos propiedades en el municipio de São Sebastião do Passé, Bahía, Brasil, durante los tres primeros meses de lactancia de 81 búfalas, para observar si las personas extrañas en sala de ordeño podrían afectar la producción de leche. Materiales y métodos. Cuatro personas extrañas estaban en la sala de ordeño durante el tiempo de ordeño para observar los siguientes parámetros: el Tiempo de Permanencia en la Sala de Ordeño; Tiempo de Ordeño; Rumiación; Defecación; Micción; Reactividad; Nivel de Estrés; Preferencia de Lado en la Sala de Ordeño; Producción de Leche y Producción de Leche Post - Control. Las búfalas fueron Categorizadas como 1, para las primíparas, 2 para las multíparas y 3 cuando la información del número de partos no fue obtenida en la 4709 
hacienda. Los análisis fueron realizados a través del Statistical Analysis System. Resultados. Durante la presencia de cuatro extraños en la sala de ordeño, se observó que el Tiempo de Permanencia en la Sala de Ordeño medio fue de 23 minutos (variando de 12 a 38 minutos) y el Tiempo de Ordeño medio de 08 minutos (variando de 4 a 13 minutos). La producción de leche media en el día de Control Lechero varió de $2.30 \mathrm{~kg}$ a $14.70 \mathrm{~kg}$, con media igual a $7.70 \pm 2.60 \mathrm{~kg}$. La producción de leche en los días siguientes fue igual a $8.60 \pm 2.70 \mathrm{~kg}$. Conclusiones. Como los animales presentaron aumento de producción lechera después del control en ambas haciendas, es posible que la presencia de personas extrañas en la sala de ordeño durante el Control Lechero mensual redujera el rendimiento apenas durante los días de observación, sin efectos adversos sobre la posterior producción de leche.

Palabras clave: Bienestar animal, Bubalus bubalis, producción animal (Source: CAB, USDA).

\section{INTRODUCTION}

The world buffalo population is estimated in approximately 177.240 millions of animals, distributed throughout forty-two countries and an annual increase of around 18 million animals per year for the last ten years (1). In Brazil, the buffalo herd amounts to 1.2 million animals (2). Murrah buffaloes are successfully bred and raised all over the country, and are appreciated for their high quality products.

Buffaloes have become an economically feasible alternative for the production of animal protein, mainly due to their adaptability, precocity and longevity (3-5). In terms of animal production, behavioral studies are relevant to determine the importance of behaviors such as rumination, defecation, urination and reaction to milking, which are closely related to animal welfare, to significant zootechnical characteristics such as milk yield, for example. With the $1.80 \%$ cumulative growth of the Brazilian buffalo herds in the past few years (6), the analysis of behavioral data and methods of evaluation are useful tools in selective breeding and targeted mating.

The increase of $20 \%$ in milk yield, observed after changes on how the animals were managed, is a strong evidence of the importance of animal welfare, not only in ethical terms but also in increased productivity $(7,9)$. In fact, some producers have already adopted raising systems based on ethological factors in order to increase animal welfare and production.

Several studies on human/animal interaction have been developed to determine the factors that negatively affect animal welfare in the milking parlor $(8,10)$. Understanding the behavior of Murrah buffaloes is relevant for stockbreeders in order to reduce the stress factors affecting welfare and productivity. At the same time, actions taken to improve animal welfare and lessen stress levels are of extreme importance in

\section{INTRODUCCIÓN}

La población mundial de búfalos se estima en aproximadamente 177.240 millones de animales, distribuidos en 42 países y con un incremento anual de aproximadamente 18 millones de animales por año en los últimos 10 años (1). En Brasil, la manada de búfalos alcanza 1.2 millones de animales (2). Los cubanos Murrah son criados exitosamente en todo el país, y son apreciados por sus productos de alta calidad.

Los búfalos se han convertido en una alternativa económica factible para la producción de proteínas ni mal, principalmente debido a su adaptabilidad, precocidad y longevidad (3-5). En términos de producción animal, los estudios de comportamientos son relevantes para determinar la importancia de comportamientos como la rumiación, defecación, micción, y reacción A los den, las cuales están relacionadas de manera cercana al bienestar del animal, a características técnicas importantes como la producción de leche, por ejemplo. Con el $1.80 \%$ de crecimiento acumulado de manadas de búfalos en Brasil en los últimos años (6), el análisis de datos de comportamiento y métodos devaluación son importantes herramientas para la cría selectiva y el apareamiento dirigido.

El incremento del $20 \%$ en la producción de leche, observado luego de cambios en cómo los animales son manejados, es fuerte evidencia de la importancia del bienestar animal, no solo en términos éticos pero también en productividad incrementada $(7,9)$. De hecho, algunos productores ya han adoptado sistemas de cría basados en factores etológicos para incrementar el bienestar y la producción del animal.

Varios estudios sobre la interacción entre humanos y animales se han desarrollado para determinar los factores que afectan negativamente el bienestar de los animales en la sala de ordeño $(8,10)$. Entender el comportamiento de los búfalos Murrah es relevante para los criadores de manera que puedan reducir los factores de estrés que afectan el bienestar y la 
favoring the implantation of organic production systems.

Therefore, it is necessary to analyze set of behavioral elements, such as characterizing the development of an ethogram, which enables the assessment of animal welfare and its implications on productivity.

This study used an ethogram to evaluate the behavior of lactating Murrah buffaloes while exposed to the presence of strangers in the milk parlor during milk control for the first three months of lactation, and to verify the influence of people in the well-being of these animals in order to assess the variation in production performance during and after periods of milk control.

\section{MATERIALS AND METHODS}

Location and production system. This study was conducted in two dairy farms located in the city Sebastião do Passé, in the state of Bahia, Brazil. Farms 1 and 2 were distant $30 \mathrm{~km}$ from each other. Climate in the region is rainy, hot and wet, with moderate winds and average rainfall of $1.65 \mathrm{~mm}$. Both farms joined the Embrapa's Buffalo Genetic Improvement Program (Empresa Brasileira de Pesquisa Agropecuária), established by Embrapa Eastern Amazon, in 2008. The study was based on the reality of the buffalo farms of the region rather than on experimental conditions and controlled environments.

Farm 1 consisted of 635 ha, with 535 ha being used for pasture rotation ( $20 \%$ of Brachiaria humidícula, $78 \%$ of Brachiaria decumbens, $2 \%$ of Brachiaria arrecta, sugar cane and Brachiaria mutica). The pastures were divided with electric fences, and water was made available at all times. Before milking, animals were transferred from pastures to an unpaved $100 \mathrm{~m}^{2}$ pre milking area without roof. The milking parlor has an automatic milking system with two lines and eight places on each side. Milk yield is automatically recorded. There were 250 lactating animals, divided into three milking groups. Calves remained with their mothers during first week of life. After this period, they only had access to the mothers during milking time, when they also received supplementary soybean meal. After milking, the females were fed a concentrate containing wheat bran, cotton seeds, soybean meal, mineral salts and barley. The amount of feed offered depended on individual milk yield. In both farms, dry cows grazed in pastures, and mineral salt was offered in feeders at all times.

Farm 2 had 600 ha, half of which were used for pasture rotation ( $60 \%$ of Brachiaria productividad. Al mismo tiempo, los acciones tomadas para mejorar el bienestar del animal y reducir los niveles de estrés son de extrema importancia para favorecer el implante de sistemas de producción orgánica.

Por ende, es necesario analizar un grupo de elementos de comportamiento, como caracterizar el desarrollo de un etograma, que permite la oración del bienestar del animal y sus implicaciones en la productividad.

Este estudio programa para evaluar el comportamiento de búfalos Murrah lactantes mientras sean expuestos a la presencia de extraños en la sala de ordeño durante el control de la leche por los primeros tres meses de lactancia, y para verificar la influencia de las personas en el bienestar de estos animales de manera que se pueda evaluar la variación en el desempeño de producción durante los periodos posteriores al control de la leche.

\section{MATERIALES Y MÉTODOS}

Locación y Sistema de Producción. Este estudio se llevó a cabo en dos fincas de chelas localizadas en la ciudad Sebastião do Passé, en el Estado de Bahía, Brasil. Las fincas uno y dos están a $30 \mathrm{~km}$ de cada una. El clima de la región es lluvioso, caliente, con vientos moderados y precipitación promedio de $1.65 \mathrm{~mm}$. Ambas fincas se unieron al Programa de Mejora Genética de Búfalos de Embrapa, establecida por Embrapa Amazonas del Este, en 2008. El estudio se basó en la realidad de las fincas de búfalos en la región En lugar de condiciones experimentales y ambientes controlados.

La finca 1 consistió de 635 ha, de las cuales 535 ha están siendo usadas para rotación de pastos (20\% de Brachiaria humidícula, $78 \%$ de Brachiaria decumbens, $2 \%$ de Brachiaria arrecta, caña de azúcar y Brachiaria mutica). Los pastizales se dividen con cercas eléctricas, y el agua está disponible en todo momento. Antes de ser ordenados, los animales son transferidos de los pastizales $A$ un área de ordeño sin pavimentar, sin techo de $100 \mathrm{~m}^{2}$. La sala de ordeño tiene un sistema automático de ordeño con dos líneas ocho posiciones en cada lado. La producción de leche se registra automáticamente. Hay 250 animales lactando, divididos en tres grupos de lactancia. Los terneros permanecen con sus madres durante la primera semana de vida. Después de este periodo, sólo tienen acceso a sus madres durante el tiempo de ordeño, cuando también reciben Una comida de soya suplementario. Luego del ordeño, las hembras son alimentadas con concentrado que contiene salvado de trigo, semillas de algodón, alimento de soya, sales minerales y cebada. La cantidad de alimento ofrecido depende en la producción individual de leche. En ambas fincas, vacas secas pastaron en los pastizales, y se les ofreció sal mineral en los alimentadores en todo tiempo. 
humidícula, $20 \%$ of Brachiaria decumbens, $1 \%$ de Pennisetum purpureum; $1 \%$ of sugar cane and $18 \%$ of overflow tolerant grass forages Echinochloa pyramidalis and Leersia hexandra). As seen in Farm 1, pastures were divided by electric fences, and there was a river flowing throughout the property providing water to the different pastures. The corral had a roofed area of $700 \mathrm{~m}^{2}$ and an area of $500 \mathrm{~m}^{2}$ without roof. It also had a scale, cattle chute and a mechanic bucket milking system with eight places into two milking lines. The farm had 140 lactating animals divided into two milking groups.

Reproductive management was similar in both farms, and the breeding season took place between the months of March and August. Timed Artificial Insemination was used from September to February. The average age for breeding varied from 18 to 25 months, and the first birthing occurred when animals were 30 to 36 months old. In both farms, all animals were vaccinated and dewormed regularly. The milking process occurred twice daily.

Management procedures such as the entry of the cows in the milking parlor, mastitis test, teat pre-dipping and drying, milking cup application and removal, post milking dipping and milk parlor exit were observed. The management in the parlor was the same for the both farms.

Data. During the morning milking, there were four strangers whose three were collecting data of milk production, and one person was observing the behavior of each buffalo at the milking line from beginning to the end of the period. Data were collected by the direct observation of 81 female buffaloes ( 52 in Farm 1, and 29 in Farm 2) during their stay in the milking parlor. Each animal were observed from its entrance and leaving the milking parlor. Animals were observed monthly during the first three lactating months, and the strangers arrived suddenly at the parlor to make sure that the animals would not be adapted to them. Milk weight was recorded twice daily (morning and afternoon). One week after these observations, a new milking observation was collected for further comparison with the Post Control Milk Yield (PCMY).

Females were categorized (CAT) as $1=$ primiparous, $2=$ pluriparous, and $3=$ when information about calving number was not available.
La finca 2 tenía 600 ha, De las cuales la mitad fue utilizada para rotación de pastos $(60 \%$ de Brachiaria humidícula, $20 \%$ de Brachiaria decumbens, $1 \%$ de Pennisetum purpureum; $1 \%$ de caña de azúcar y $18 \%$ de forrajes de pasto tolerante al sobre flujo Echinochloa pyramidalis y Leersia hexandra). Como se vio en la finca número uno, los pastizales fueron divididos por cercas eléctricas, Y había un río que fluya a través de la propiedad proporcionando agua a los diferentes pastizales. El corral tenía un área techada de $700 \mathrm{~m}^{2}$ y un área de $500 \mathrm{~m}^{2}$ sin techo. También tenía una balanza, una rampa de ganado y un sistema de ordeño mecánico con ocho plazas en dos líneas de ordeño. La finca tenía 140 animales lactando divididos en dos grupos de ordeño.

El manejo reproductivo fue similar en ambas fincas, y la estación de cría lugar entre los meses de marzo y agosto. Inseminación artificial cronometrada fertilizada desde septiembre hasta febrero. La edad promedio para quilla varía entre 18 y 25 meses, y el primer nacimiento ocurrió cuando los animales tenían entre 30 y 36 meses. En ambas fincas, todos los animales fueron vacunados $Y$ desparasitado regularmente. El proceso de ordeño ocurrió dos veces al día.

Los procedimientos de gestión tales como la entrada de las vacas en la sala de ordeño, las pruebas de mastitis, pre-goteo y secado del pezón, aplicación y remoción de la tasa de leche, inmersión posterior al ordeño Y salió de la sala fueron observados. La gestión en la sala fue la misma en ambas fincas.

Datos. Durante el ordeño en la mañana, hubo cuatro extraños de los cuales tres recolectaban datos sobre la producción de leche, y una persona estaba observando el comportamiento de cada búfalo en la línea de ordeño desde el principio hasta el final del periodo. Los datos fueron recolectados por medio de observación directa de 81 búfalos hembra (52 en la finca uno, y 29 en la finca dos) durante su estadía en la sala de ordeño. Cada animal fue observado desde su entrada y salida de la sala de ordeño. Los animales fueron observados mensualmente durante los primeros tres meses de lactancia, y los extraños Llegaban de repente a la sala para asegurarse de que los animales no se hubieran adaptado a ellos. El peso de la leche era registrado dos veces al día (mañana y tarde cierro paréntesis. Una semana después de estas observaciones, una nueva observación de ordeño era recolectada para comparación adicional con el Post Control de Producción de Leche (PCMY por sus siglas en inglés).

Las hembras fueron categorizadas (CAT) como $1=$ primíparas, 2 = pluríparas, y $3=$ cuando la información sobre el número de terneros no estaba disponible. 
Continuous variables. The focal sampling and continuous collection followed a model adapted from ethogram of Paranhos da Costa and Broom (8), Hötzel (11) and Honorato (12). The behavioral variables bellows was observed:

Period in the Milking Parlor (PMP): measured as the time from entrance into the parlor until the animals were set free; Milking Period (MP): measured in minutes, from the moment of the milking cups were applied until their removal from animals; Milk Yield (MY): amount in $\mathrm{kg}$ of milk produced during observation days; Post Control Milk Yield (PCMY): amount in kg of milk produced one week later the first observation, without the presence of strangers in the milking parlor.

Discrete variables. The variables recorded as observed or not necessarily in the milking parlor (Rumination - RU, Defecation - DEF, Urination - UR).

Modal scores. Other measurements observed in the milking parlor:

Reactivity (REAC): defined as the actions or movements of the animal during milking (8):

1.) Yes or not leg movements;

2.) If there were legs movement:

2.1) lifted less than $15 \mathrm{~cm}$ above the ground;

2.2) lifted more than $15 \mathrm{~cm}$ above the ground.

Stress Level (SL): behavior of the animals in the milking parlor:

1.) Agitated: eyes wide-open, raised ears;

2.) Slightly agitated: watchful, staring, ear movements towards the noise source, interruption of current activity;

3.) Calm: head and ears down, drowsy;

Side Preference in the Milking Parlor (SPMP):

1.) Right side of the line;

2.) Left side of the line.

Statistical analysis. The continuous variables PMP, MP, MY and PCMY were analyzed using the SAS Statistical Package (13). To determine if Farm had a fixed effect on the discrete variables $R U, D E F$ and UR, the GENMOD procedure of SAS was used. The modal scores for REAC (REACMO), SL (SLMO) and SPMP (SPMPMO) were considered fixed effects using the GLM procedures in analysis models that also consider Farm and CAT as fixed effects on the variables MY and PCMY.

Mean comparison tests for significant effects were performed (Tukey's test for CAT and SL or REACMO, and t-test for Farm and SPMP). For rank correlation in both farms between MY and
Variables Continuas. El muestreo focal y la recolección continua siguieron un modelo adaptado del etograma de Paranhos da Costa y Broom (8), Hotzel (11) y Honorato (12). Las variables de comportamiento a continuación se observaron:

Periodo en la sala de ordeño (PMP por sus siglas en inglés): medido Como el tiempo desde la entrada en la sala hasta que los animales eran liberados; periodo de ordeño (MP por sus siglas en inglés): Medido en minutos, desde el momento en que las copas eran aplicadas hasta su remoción de los animales ; Producción de leche (MP por sus siglas en inglés): cantidad en kilogramos de leche producida durante los días de observación; Post Control de Producción de Leche (PCMY por sus siglas en inglés): cantidad en kilogramos de leche producida una semana después de la primera observación, sin la presencia de extraños en la sala de ordeño.

Variables Discretas. Las variables registradas como se observaron o no necesarias en la sala de ordeño (Rumiación - RU, Defecación - DEF, Micción - UR).

Calificaciones Modales. Otras medidas observadas en la sala de ordeño:

Reactividad (REAC): definidas como las acciones son movimientos del animal durante el ordeño (8):

1.) Movimientos de piernas si o no;

2.) Si hubo movimiento de piernas:

2.1) Levantadas menos de $15 \mathrm{~cm}$ sobre el suelo;

2.2) Levantadas más de $15 \mathrm{~cm}$ sobre el suelo;

Nivel de Estrés (SL por sus siglas en inglés): comportamiento de los animales en la sala de ordeño:

1.) Agitados: ojos abiertos, orejas levantadas;

2.) Un poco agitados: vigilante, mirando, movimiento de las orejas hacia la fuente del ruido, interrupción de actividad actual;

3.) Calmados: cabeza y orejas abajo, mareados;

Preferencia de lado de la sala de ordeño (SPMP por sus siglas en inglés):

1.) Lado derecho de la línea:

2.) Lado izquierdo de la línea.

Análisis Estadístico. Las variables continuas PMP, MP, MY y PCMY fueron analizadas utilizando el paquete estadístico SAS (13). Para determinar si la Finca tiene un efecto fijo en las variables discretas RU, DEF y UR, el procedimiento GENMOD de SAS fue utilizado. Las calificaciones modales para REAC (REACMO), SL (SLMO), y SPMP (SPMPMP) fueron consideradas efectos fijos utilizando los procedimientos GLM en modelos de análisis que también consideran Finca y CAT como efectos fijos en las variables MY y PCMY. 
PCMY, the SAS PROC CORR SPEARMAN procedure was applied.

The chi-square test was used to test the following hypothesis: (alpha=0.05): HO - rumination ratio is the same in both farms; $\mathrm{H} 1$ - rumination ratio is not the same in both farms; $\mathrm{HO}$ - defecation ratio is the same in both farms; $\mathrm{H} 1$ - defecation ratio is not the same in both farms; $\mathrm{HO}$ - urination ratio is the same in both farms; H1- urination ratio is not the same in both farms.

\section{RESULTS}

The mean value for the Period in Milking Parlor (PMP) was of 23 minutes (varying from 12 to $38 \mathrm{~min}$ ), and the mean Milking Period was of $8 \mathrm{~min}$ (varying from 4 to $13 \mathrm{~min}$ ). Average milk yield during observation days (MY) varied from $2.30 \mathrm{~kg}$ to $14.70 \mathrm{~kg}$, with a mean value of $7.70 \pm 2.60 \mathrm{~kg}$. Mean milk yield on the days after observations was $8.60 \pm 2.70 \mathrm{~kg}$, varying from $3.70 \mathrm{~kg}$ to $17.30 \mathrm{~kg}$ (Table 1 ).

Table 1. Mean, standard deviation (SD), minimum (Min) and maximum (Max) of the continuous variables PMP, MP, MY and PCMYstudied in Murrah buffaloes.

\begin{tabular}{cccccc}
\hline Variables & N & Mean & SD & Min & Max \\
\hline PMP (min) & 81 & 22.8 & 4.1 & 12.0 & 37.7 \\
MP (min) & 81 & 8.0 & 1.9 & 4.3 & 13.0 \\
MY (kg) & 81 & 7.7 & 2.6 & 2.3 & 14.7 \\
PCMY (kg) & 81 & 8.6 & 2.7 & 3.7 & 17.3 \\
\hline
\end{tabular}

MP (Period in the Milking Parlor, measured as the time from entry into the parlor until the animals were set free); MP (Milking Period, measured in minutes from the moment the milking cups were applied until their removal from animals); MY (Milk Yield, amount in $\mathrm{kg}$ of milk obtained during observation days); PCMY (Post Control Milk Yield, values obtained one week after the first observations).

In the present study, animals could choose to be milked on the right or the left side of the milking lines. Overall, animals from Farm 1 preferred the left side of the line, while animals from Farm 2 preferred the right side of the milking line.

One hundred and fifty six observations from Farm 1 and eighty seven from Farm 2 were performed regarding the following behavioral parameters: Rumination, Urination and Defecation. The results, expressed as percentage, are shown in table 2 .
Las comparaciones de pruebas de media para efectos significativos fueron realizadas (Prueba Tukey para CAT y SL o RACMO, prueba t para Finca y SPMP). Para correlación de rango en ambas fincas entre MY y PCMY, se aplicó el procedimiento de SAS PROC CORR SPEARMAN.

La prueba chi-cuadrado se utilizó para probar la siguiente hipótesis (alpha=0.05); HO-tasa de rumiación igual en ambas fincas; $\mathrm{H} 1$-tasa de rumiación no es la misma en ambas fincas; HO-tasa de defecación es la misma en ambas fincas; $\mathrm{H} 1$ - tasas de defecación no es la misma en ambas fincas; $\mathrm{HO}=$ tasa de micción es la misma en ambas fincas; $\mathrm{H} 1$ = tasa de micción no es la misma en ambas fincas.

\section{RESULTADOS}

El valor medio para el Periodo en la Sala de Ordeño (PMP) fue de 23 minutos (variando entre 12 y 38 minutos9, y el Periodo de Ordeño medio fue de 8 minutos (variando entre 4 y 13 minutos). La producción promedio de leche durante los días de observación (MY) varió entre $2.30 \mathrm{~kg}$ y $14.60 \mathrm{~kg}$, con un valor medio de $7.70 \pm 2.60$ $\mathrm{kg}$. La producción media de leche en los días de observación fue de $8.60 \pm 2.70 \mathrm{~kg}$, variando entre $3.70 \mathrm{~kg}$ a $17.30 \mathrm{~kg}$ (Tabla 1 ).

EI MP (Periodo en la Sala de ordeño, medido como el tiempo desde la entrada en la sala de ordeño hasta que los animales fueron liberados); MP (periodo de ordeño, medio en minutos desde el momento en que las copas de ordeño fueron aplicadas hasta su remoción de los animales); MY (producción de leche, cantidad en kilogramos de leche obtenida durante los días de observación); PCMY (Post Control Producción de Leche, valores obtenidos una semana después de las primeras observaciones).

En el estudio actual, los animales podían escoger ser ordeñados en el lado derecho o izquierdo de las líneas de ordeño. En general, los animales de la finca uno prefirieron el lado izquierdo de la línea, mientras que los animales de la finca dos prefirieron el lado derecho de la linea de ordeño.

Se realizaron Ciento cincuenta y seis observaciones de la finca 1 y ochenta y siete de la finca 2 con respecto a los siguientes parámetros de comportamiento: rumiación, orinar y defecación. Los resultados, expresados en porcentaje, se muestran en la tabla 2.

De acuerdo a los datos, las variables presentan diferentes tasas en ambas fincas. Las pruebas chi-cuadrado $(p<0.05)$ indican que no hubo 
Table 2. Behavioral variables Rumination (RU), Urination (UR) and Defecation (DEF) expressed as percentage.

\begin{tabular}{lcccc}
\hline \multirow{2}{*}{ Variable } & \multicolumn{2}{c}{ Farm 1 } & \multicolumn{2}{c}{ Farm 2 } \\
\cline { 2 - 5 } & Yes & No & Yes & No \\
\hline Rumination (RU) & 34 & 66 & 14 & 86 \\
Urination (UR) & 23 & 77 & 10 & 90 \\
Defecation (DEF) & 11 & 89 & 8 & 92 \\
\hline
\end{tabular}

According to the data, all variables presented different ratios in both farms. Chi-square tests $(p<0.05)$ indicate that there were no equal ratios between farms for the variables urination and rumination (the expected $X^{2}$ were higher than the observed $x^{2}$ for 1 d.f.), which is in agreement with the data in table 2.

Only six female buffaloes with Reactivity (REAC) index of 3 (legs lifted more than $15 \mathrm{~cm}$ above the ground) were observed in Farm 1. For the variable level of stress (SL), it was observed only one buffalo scoring in all observations. The same animal was classified as agitated and presented leg agitation.

According to the statistical model applied, the modal score of Stress Level (SLMO) for Milk Yield (MY) was significant $(p<0.0001)$, i.e., farm, CAT and SLMO explained $44 \%$ of the MY variation. However, the characteristic "Farm" had no significant effect on MY $(p>0.60)$. During milking control days, calm females produced 3 $\mathrm{kg}$ more than what was recorded on days after observation days. Pluriparous animals produced $1.60 \mathrm{~kg}$ more than the primiparous females. Older females produced $2.80 \mathrm{~kg}$ more milk in the absence of strangers. Therefore, the yield decreases more evident in this category (9.80 $\mathrm{kg}$ of milk compared to $7.00 \mathrm{~kg}$ during the milk control recording day).

Reactivity modal scores (REACMO) for Milk Yield (MY) were significant ( $p<0.0001)$. Farm, Category (CAT) and REACMO explained for 34\% of the Milk Yield (MY) variation. However, the characteristic "Farm" had no significant effect on MY ( $p>0.70)$, and no significant differences ( $p>0.05)$ among REAC 1, 2 and 3 were observed. In terms of PCMY, the statistical model explained for 35\% of the variation and was significant $(p<0.0001)$. The effect of CAT was not significant $(p>0.09)$. Tukey's test indicated that females within modal score 1 (motionless legs) produced $1.70 \mathrm{~kg}$ more than those in modal score 3 (legs $15 \mathrm{~cm}$ above the ground). Farm 1 had an statistically higher production than Farm 2 ( $p<0.05)$, with an average milk yield of $2.00 \mathrm{~kg}$ more per animal on the days after milk control observations with the presence of strangers (Figure 1). tazas iguales entre las fincas para las variables de micción y rumiación (las $X^{2}$ esperadas fueron mayores que las $X^{2}$ observadas para 1d.f), lo cual está acorde con los datos de la tabla dos.

Sólo seis búfalos hembra con índice de reactividad (REAC) de 3 (patas levantadas más de $15 \mathrm{~cm}$ sobre el suelo) se observaron en la finca uno. Para la variable de nivel de estrés ( $S L$ ), se observó sólo un búfalo calificando en todas las observaciones. El mismo animal fue clasificado como agitado y presento agitación de patas.

De acuerdo al modelo estadístico aplicado, la calificación modal de nivel de estrés (SLMO) la producción de leche (MY) fue significativa $(p<0.0001)$, ej. Finca, CAT y SLMO explican $44 \%$ de la variación de MY. Sin embargo, la característica "finca" no tuvo ningún efecto significativo en MY $(p>0.60)$. Durante los días de control de ordeño, las hembras calmadas produjeron $3 \mathrm{~kg}$ más que lo que fue registrado en días después de los días de observación. Los animales pluríparos produjeron 1.60 kilogramos más que las hembras primíparas. Las hembras más viejas produjeron: $30 \mathrm{~kg}+$ leche en ausencia de extraños. Por esto, la producción disminuye más evidentemente en esta categoría ( 9.80 kilogramos de leche comparados con $7.00 \mathrm{~kg}$ durante el día de registro de control de leche).

Las calificaciones modales de reactividad (REACMO) la producción de leche (MY) fueron significativas $(p<0.0001)$. Finca, Categoría (CAT) y REACMO explican $34 \%$ de la variación en producción de leche (MY). Sin embargo, la característica "finca" no tuvo ningún efecto significativo en MY ( $p>0.70, Y$ no hubo diferencias significativas ( $p>0.05)$ entre REAC 1, 2, y 3 cuando se observaron. En términos de PCMY, el modelo estadístico explica $35 \%$ de la variación y fue significativo $(p<0.0001)$. El efecto de CAT no fue significativo $(p>0.09)$. La prueba de Tukey indicó que las hembras dentro de la calificación modal 1 (patas inmóviles) produjeron 1.70 kilogramos más que aquellas con calificación modal de 3 (patas $15 \mathrm{~cm}$ sobre el suelo). La finca uno tuvo una producción estadísticamente mayor que la finca $2(p<0.05)$, con una producción promedio de leche de $2.00 \mathrm{~kg}$ más por animales en los días después de las observaciones de control de leche en la presencia de extraños (Figura 1).

De acuerdo al modelo estadístico aplicado, la calificación moral para preferencia de lado (SPMPMO) para Producción de Leche (MY) fue significativa $(p<0.0001)$, con un R-cuadrado de $21 \%$. Finca, CAT y SPMPMP explican $21 \%$ de la variación de MY observada. En ambas fincas, 


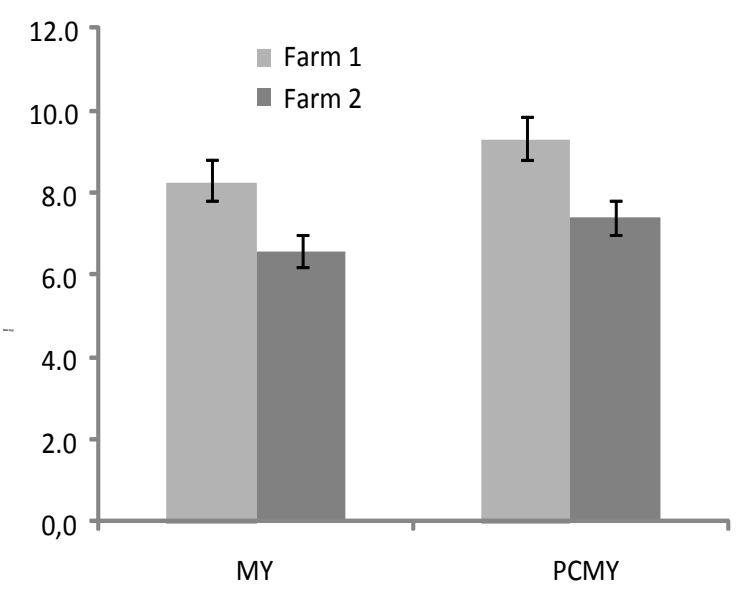

Figure 1. Milk production on daily Control (MY) and the Post Control Milk Yield (PCMY) in the two herds of Murrah buffaloes studied.

According to the statistical model applied, the modal score of Side Preference (SPMPMO) for Milk Yield (MY) was significant $(p<0.0001)$, with a R-square of $21 \%$. Farm, CAT and SPMPMO explained for $21 \%$ of the observed MY variation. In both farms, side preference (SPMPMO) had no significant effect ( $p>0.70$ ) on MY during milk control days. In terms of PCMY, the model was significant $(p<0.009)$ with a low R-square of $16 \%$. CAT, Farm and SPMPMO were not significant $(p>0.15)$. Side preference in the milking parlor was not a significant source of variation in milk yield. The overall rank correlation between PLO and PLP was equal to 0.76. There was a $24 \%$ change in the ranking of the animals for the two periods studied. When the analysis was done by farm, the correlation rank of Farm 1 was equal to 0.74 (or $26 \%$ change in scoring), while Farm 2 was equal to 0.58 (ie $42 \%$ change in ranking). The change in rank may be an indicative of the influence of presence of strangers in the milk parlor in the buffalo's milk production, because there were considerable changes in the classification of buffaloes between periods.

\section{DISCUSSION}

The mean value for period in Milking Parlor (PMP) was 23 minutes (ranging from 12 to 38 minutes), and the mean of the Milking Period was 8 minutes (ranging from 4 to 13 minutes). Average milk yield during observation days (MY) ranged from $2.30 \mathrm{~kg}$ to $14.70 \mathrm{~kg}$, with a mean value of $7.70 \pm 2.60 \mathrm{~kg}$. Mean milk yield one week after the observation days was $8.60 \pm 2.70 \mathrm{~kg}$, ranging from $3.70 \mathrm{~kg}$ to 17.30 $\mathrm{kg}$, which suggests the interference of stranger in the parlor on buffaloes milk production. Peters et al (14) observed higher values for PMP, with TOR being higher in cows that were not subjected to aversive handling $(\mathrm{PCMY}=9.6 \mathrm{~min}$ and $\mathrm{MP}=7.3$ preferencia de lado (SPMPMO) no tuvo un efecto significativo $(p>0.70)$ en MY durante los días de control de leche. En términos de PCMY, el modelo fue significativo $(p<0.009)$ con un bajo R-cuadrado de $16 \%$. CAT, Finca y SPMPMO no fueron significativos $(p>0.15)$. La preferencia de lado en la sala de ordeño no fue una fuente significativa de variación en la producción de leche. El rango General de correlación entre PLO y PLP fue igual a 0.76 . Hubo un $24 \%$ de cambio en el rango de los animales para los dos periodos estudiados. Cuando el análisis fue hecho por la finca, el rango de correlación para la finca uno fue igual a $0.74(26 \%$ de cambio en la calificación), mientras que la finca dos fue igual a 0.58 (ej. $42 \%$ de cambio en rango). El cambio puede ser un indicativo de la influencia de la presencia de extraños en la sala de ordeño en la producción de leche de los búfalos, Porque no hubo cambios considerables en la clasificación de los búfalos que entre periodos.

\section{DISCUSIÓN}

El valor medio para el periodo en la sala de ordeño (PMP) fue de 23 minutos (oscilando entre 12 y 38 minutos), Y la media del periodo de ordeño fue ocho minutos (oscilando entre cuatro y 13 minutos). La producción promedio de leche durante los días de observación (MY) varió entre 2.30 kilogramos 14.70 kilogramos, con un valor medio de $7.70 \pm 2.60 \mathrm{~kg}$. La producción media de leche una semana después de los días de observación fue de $8.60 \pm 2.70 \mathrm{~kg}$, oscilando entre $3.70 \mathrm{~kg}$ y 17.30 kilogramos, lo que sugiere una interferencia del extraño en la sala de ordeño en la producción de leche de los búfalos. Peters et al. (14) observó mayores valores de MP, con TOR mayor en vacas que no estuvieron sujetas a manejo aversivo $(\mathrm{PCMY}=9.6$ minutos y $\mathrm{MP}=7.3$ minutos para no aversivo y $\mathrm{DSMP}=9.2$ minutos y $M P=7.0$ minutos para manejo aversivo). De acuerdo con los autores, el MP mayor en animales sometidos a manejo aversivo No puede deberse al manejo pacífico y el respeto por la velocidad del movimiento de los animales, el cual incremento el tiempo hasta que los animales se acomodaban en la sala.

Las vacas bajo estrés mostraron resistencia a entrar en la sala de ordeño, Obstaculizando el trabajo Del ordenador y, consecuentemente, presentando una reducción en la producción de leche $(15,16)$. La producción de leche afectó el PCMY y MP manera significativa. En consecuencia, el tiempo gastado en la sala de ordeño y el tiempo de ordeño interfirió en la eficiencia del proceso de ordeno.

Se conoce que el desempeño es afectado por los estímulos externos, que los animales 
min for non-aversive and DSMP $=9.2 \mathrm{~min}$ and $\mathrm{MP}=7.0 \mathrm{~min}$ for the aversive handling). According to the authors, the higher MP in animals submitted to aversive handling could not be due to the peaceful management and respect for the speed of movement of animals, which increased the time until the animals had settled in the parlor.

Cows under stress showed resistance to enter the milking parlor, hampering the work of the milkier and, consequently, presenting a reduction in milk production $(15,16)$. Milk production affected the PCMY and MP significantly. Therefore, the time spent in the milking parlor and the milking time interfered at the efficiency of the milking process.

It is known that performance is affected by external stimuli, and that animals can perceive specific situations as pleasant or unpleasant in relation to previous experiences (17-19). The preferences of which side to be milked may be related to the way the spaces are used in both sides of the milking lines (passageway for calves and humans, for example). A research carried out by Marcondes et al (20), in Farm 1 with the observation of 248 animals, showed that $54.3 \%$ of the females chose the same side of the milking line. In a study performed by Grasso et al (19), focusing on the relation between entry of bovines in the milking parlor and milk yield, the authors observed a negative correlation for multiparous females and a positive correlation for primiparous females. However, Alves (21) observed no difference in milk production between different categories of females.

Although both Farms belonged to the same owner, daily management differed in terms of feeding and human-animal interactions. The presence of strangers in Farm 2 during Milk Control (MC) days does not affect animal comfort, as suggested by the data in table 2. High incidence of defecation, urination and reactive animals, with a higher frequency of negative actions in the milking parlor, may have reflected impaired animal welfare (9).

The low reactivity scores in categories 1 and 2 suggested that the behavioral interference was neutral, with the exception of Milk Production during observation days. Stress Level 1 (agitated) in all observations was found in only one female, which also presented leg movement. Such behavior can indicate that improvements in the routine procedures of the farm may be required (8). As reported by Lewis and Hurnik (22), previous negative experiences may increase animal reactivity. Harmonic human-animal interactions reduced stress reactions and reactivity to humans, thus facilitating handling (23-25) without impairing daily production. pueden percibir situaciones específicas como agradables o desagradables en relación con experiencias previas (17-19). Las preferencias sobre el lado en el que van hacer ordeñados puede relacionarse con la manera en que los espacios son usados en ambos lados de las líneas de ordeño (corredores para terneros y humanos, por ejemplo). Una investigación hecha por Marcondes et al (20), en la finca uno con la observación de 248 animales, mostró que el $54.3 \%$ de las hembras escogió el mismo lado de la línea de orden. En un estudio hecho por Grasso et al (19), enfocado en la relación entre la entrada de bovinos en la sala de ordeño y la producción de leche, Los autores observaron una correlación negativa para hembras multíparas y una correlación positiva para hembras primíparas. Sin embargo, Alves (21) no observo diferencias en la producción de leche entre las diferentes categorías de hembras.

Aunque ambas fincas que eran del mismo dueño, la gestión diaria de feria en términos de alimentación interacción entre animales y humanos. La presencia de extraños en la finca dos durante los días de control de leche (MC) no afecta el confort del animal, como lo sugieren los datos en la tabla dos. Una alta incidencia de defecación, micción y reactividad animal, con una mayor frecuencia de acciones negativas en la sala de ordeño puede a ver reflejado deterioro del bienestar de los animales (9).

Las bajas calificaciones de reactividad en las categorías 12 sugieren que la interferencia de comportamiento fue neutra, con la excepción de producción de leche durante los días de observación. El nivel de estrés uno (agitado) En todas las observaciones se encontró solo en una hembra, que también presentó movimiento de patas. Dicho comportamiento puede indicar que se pueden requerir mejoras en los procedimientos de rutina de la finca. Como lo reportaron Lewis y Hurnik (22), las experiencias negativas anteriores pueden incrementar la reactividad animal. Interacciones armónicas entre humanos y animales Redujeron las reacciones de estrés y reactividad a los humanos, facilitando el manejo (23-25) si no obstaculizar la producción diaria.

La presencia esporádica extraños en las líneas de ordeño no parece afectar el comportamiento animal y no es seguida por una reducción en la producción de leche (22). La presencia de humanos conocidos durante los procedimientos de control puede contribuir a reducir los efectos negativos de la presencia de extraños sobre comportamiento animal (10). Nuestros resultados también mostraron que la presencia de personas conocidas durante el control de 
The sporadic presence of strangers in the milking lines does not seem to affect animal behavior and is not followed by a reduction in milk yield (22). The presence of known humans during the control procedures might contribute to reduce the negative effects of the presence of strangers on animal behavior (10). Our results also showed that the presence of known people during Milk Control (MC) does not contribute to reduce the negative effects of the presence of strangers on MY. It is well known that bovines like routine and, since they tend to have a good memory, they can discriminate humans involved in the interactions by reacting in specific ways (23), such as inhibiting milk ejection (26), and reducing daily milk yield (21).

Changes in the daily routine of the animals may cause discomfort and interfere with their daily production (14). This may be evidenced by changes in the ranking of the MY, and PCMY animals. The milk production of buffaloes on a farm may increase as changes are made in the management to meet the behavioral needs of animals $(7,24)$.

In conclusion the results of the current study of the behavior of Murrah females in Bahia, Brazil, showed a reduction of milk yield on milk control days due to the presence of strangers in the milking parlor. The negative effects, however, subsided as soon as the observation was concluded and the presence of strangers in the milking parlor was removed, therefore, not affecting the subsequent milk yield of the animals.

\section{Acknowledgements}

The authors thank the farmer Urbano Antônio de Souza Filho for providing the animals and support research. leche (MC) no contribuye a reducir los efectos negativos de la presencia de extraños sobre MY. Es de amplio conocimiento que los bovinos aprecia en la rutina, debido a que tienden a tener una buena memoria, pueden discriminar entre humanos involucrados en interacciones reaccionando en maneras específicas (23), tales como inhibiendo la eyección de leche (26) y reduciendo la producción diaria de leche (21).

Los cambios en la rutinas diarias de los animales pueden causar Malestar en interferir con su producción diaria (14). Esto se puede evidenciar por cambios en el rango de animales MY y PCMY. La producción de leche de búfalos en una finca puede incrementar a medida que se hacen cambios en la gestión para Satisfacer las necesidades de comportamiento de los animales $(7,24)$.

En conclusión los resultados del estudio actual sobre el comportamiento de hembras Murrah en Bahía, Brasil, mostró una reducción en la producción de leche en los días de control de leche debido a la presencia de extraños en la sala de ordeño. Los efectos negativos, sin embargo, subsiguieron tan pronto la observación fue concluida y la presencia de extraños en la sala de ordeño fue removida, entonces, no afectó la producción de leche subsiguiente en los animales.

\section{Agradecimientos}

Los autores agradecen al agricultor Urbano Antonio de Souza Filjo por proporcionar los animales y el apoyo en la investigación.

\section{REFERENCES}

1. Sethi RK. Buffalo improvement program in India. Rev Vet 2010; 21(1):5.

2. Ramos AA, Malhado CHM, Carneiro PLS, Azêvedo DMMR, Gonçalves HC. Caracterização fenotípica e genética da produção de leite e do intervalo entre partos em bubalinos da raça Murrah. Pesq Agropec Bras 2006; 41(8):1261-1267.

3. Jorge AM. Produção de carne bubalina. Rev Bras de Reprod Anim 2005; 29(2):84-95.
4. Cassiano LAP, Mariante NA. Parâmetros genéticos das características produtivas e reprodutivas de búfalos na Amazônia. Pesq Agropec Bras 2004; 39(5):451-457.

5. Garcia AR. Influência de fatores ambientais sobre as características reprodutivas de búfalos do rio (Bubalus bubalis). Rev de Ciênc Agrár 2006; 45:1-13.

6. Bernardes O. Bubalinocultura no Brasil: situação e importância econômica. Rev Bras Reprod Anim 2007; 31:293-298. 
7. Dawkins, MS. A user's guide to animal welfare Science. Trends Ecol Evol 2006; 21:77-82.

8. Paranhos Da Costa MJR, Broom DM. Consistency of side choice in the milking parlour by Holstein-Friesian cows and its relationship with their reactivity and milk yield. Appl Anim Behav Sci 2001; 70(3):177-186.

9. Hanna D, Sneddon IA, Beattie VE. The relationship between the stock person's personality and attitudes and the productivity of dairy cows. Animal 2009; 3:737-743.

10. Hötzel MJ, Gomes CCM, Machado Filho LCP. Comportamento de vacas leiteiras submetidas a um manejo aversivo. Biotemas 2009; 22:135-140.

11. Hötzel MJ, Machado Filho LCP, Yunes MC, Silveira MCAC. An aversive milker causes fear, but does not influence milk yield of Holstein cows. Braz J Anim Sci 2005; 34:1278-1284.

12. Honorato LA, Hötzel MJ. A interação humano-animal e o uso de homeopatia no manejo sanitário de rebanhos leiteiros em pequenas propriedades no Sul do Brasil. Rev Bras de Agroec 2012; 7(2):77-86.

13. SAS. Statistical Analysis System - SAS Version 9.0, $13^{\text {th }}$ ed. Cary: Statistical Analysis System Institute; 2004.

14. Peters MDP, Barbosa Silveira ID, Pinheiro Machado Filho LC, Machado AA, Pereira LMR. Manejo aversivo em bovinos leiteiros e efeitos no bem-estar, comportamento e aspectos produtivos. Arch Zootec 2010; 59(227):435-442.

15. Breuer K, Hemsworth PH, Coleman GJ. The effect of positive or negative handling on the behavioural and physiological responses of non lactating heifers. Appl Anim Behav Sci 2003; 84(1):3-22.

16. Costa JHC, Hötzel MJ, Longo C, Balcão LF. A survey of management practices that influence production and welfare of dairy cattle on family farms in southern Brazil. J Dairy Res 2013; 96(1):307-317.
17. Broom DM, Molento CFM. Bem-estar animal: conceito e questões relacionadas - revisão. Arch Vet Sci 2004: 9:1-11.

18. Molento CFM. Bem-estar animal: qual é a novidade? Acta Sci Vet 2007; 35(2):224-226.

19. Grasso F, De Rosa G, Napolitano F, Di Francia A, Bordi A. Entrance order and side preference of dairy cows in the milking parlour. Ital J Anim Sci 2007; 6:187-194.

20. Marcondes $C R$, Andréa MV, Oliveira KN, Oliveira RS, Macedo Junior CM, Cerqueira RS et Al. Side Preference in the Milking Parlor Among Murrah Buffaloes in the Recôncavo of Bahia, Brazil. Rev Vet 2010; 21(1):598-599.

21. Alves BG, Silva TH, Igarasi MS. Manejo de ordenha. PUBVET 2013: 7(6): Art. 1514. URL Disponible en: http://www.pubvet. com.br/artigos_imp.asp?artigo $=1402$

22. Lewis NJ, Hurnik J F. The effect of some common management practices on the ease of handling of dairy cows. Appl Anim Behav Sci 1998; 58:213-220.

23. Honorato LA, Hötzel MJ, Gomes CCM, Silveira IDB, Pinheiro Machado Filho LC. Particularidades relevantes da interação humano-animal para o bem-estar e produtividade de vacas leiteiras. Cienc Rural 2012; 42(2):332-339.

24. Watters RD, Schuring N, Erb HN, Schukken $\mathrm{TH}$, Galton DM. The effect of premilking udder preparation on Holstein cows milked 3 times daily. J Dairy Sci 2012; 95:1170-1176.

25. Waiblinger S, Mulleder C, Schmied C, Dembele I. Assessing the animals' relationship to humans in tied dairy cows: between-experimenter repeatability of measuring avoidance reactions. Anim Welf 2007; (16):143-146.

26. Breazile, JE. The Physiology of Stress and Its Relationship to mechanisms of Disease and therapeutics. Vet Clin N Am: Food Anim Prac 1988; 4:441-480. 